\title{
Identity Crisis of Lyndall in Schreiner's The Story of an African Farm
}

\author{
Dr. Ramesh Prasad Adhikary
}

Assistant Professor

Tribhuwan University

Mahendra Multiple Campus

Nepalgunj, Nepal

rameshadhikary29@gmail.com

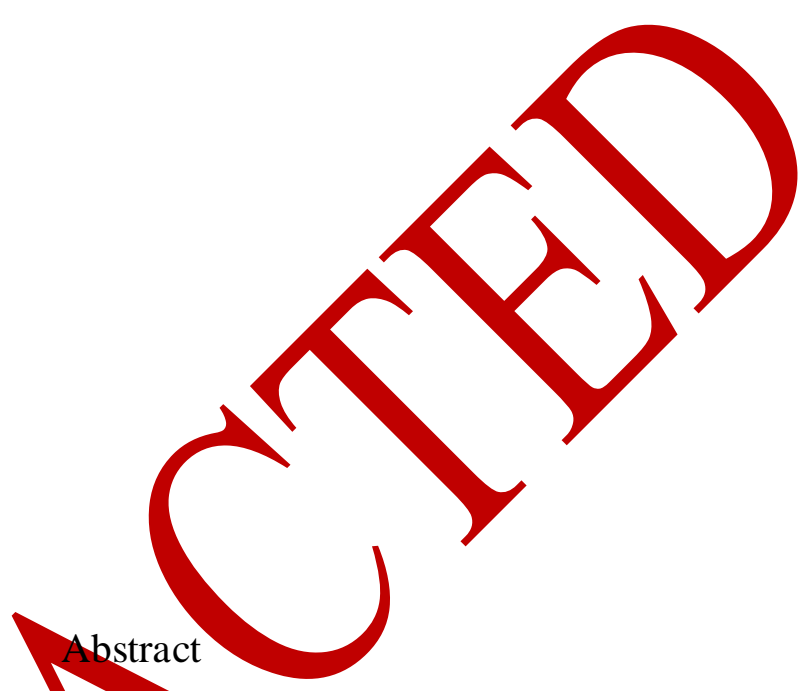

In this research paper, the researcher explore how the female identity was in crisis in the colonized Africa. Olive Schreuner's The Story of an African Farm is taken as a primary text to explore the exploitation of colonizers by interpreting it with the tool of postcolonial literary theory. African farm owners were displaced from their farm landscape by the colonizers. As a result, the farm workers have to face the problem of identity crisis. Englishmen were responsible for bringing Africans identity crisis. They struggle to establish their identity on the Karoo farmland. The main victims were women whose identity is determined in relation to the place. Their placelessness represents their identity crisis in the Karoo farm landscape. Women's identity is connecting with the place. As a qualitative research, the researcher has extensively presents the crisis of identity of female in their own land when the colonizers seized their land.

Key Terms: Identity, Colonialism, Dislocation, Postcolonialism, Feminism. 


\section{Introduction}

The novel, The Story of an African Farm, was published under the pseudonym of Ralph Iron in 1883 , but her real name was Olive Schreiner. The novel is based on real background of South African farm landscape, Karoo, and African people's life on the farm. The main protagonist, Lyndall has to face the crisis of identity as the colonizers took her land.

Olive Schreiner's novel, The Story of an African Farm, focused on the issues of females who is in the quest of self-identity and space in the Karoo farm landscape it is also about the new settlers struggle hard to adapt changing natural circumstances of the Karoo farm landscape, because they are new in the farm land For them, place determines the peoples' identity but colonizers took farm land. And this displacement has its effects upon the identity formation of females. The separation from the farm land causes them the loss of natural, cultural and spiritual root. The displaced new settlers feel a sense of alienation from the Karoo farm land and lack of identity.

The owner of the farm land were Otto, a German overseer and a widow called Tan't Sannie, Otto's son Waldo and two young girls, Lyndall and Em. The land where they run a sheep farm was called Karoo, which was situated in South Africa. This place is suitable for African new settlers, where they explore the relation between individual and the land itself as a process of identity formation. Thus, Farm is the significant place in the South, particularly with its colonial past and present implication for the land reform.

Furthermore, the problem of colonial identity formation is reflected in the identity formation of female protagonist, Lyndall opposes the values for getting her identity and place in that farm land. She cannot easily get this identity in the colonial context. In the colonial context, place and identity are under the control of colonizer. They do not want to give them identity and place because they have fear about losing their colony from the new settlers. 
This research paper tries to find out the connection between the place and identity. How does the novel contribute to the formation of female identity in connection to the place? In the novel, Lyndall wants to make her identity with her connection to the farm. She is questing both identity and place in the Karoo farm landscape. She didn't get it in the farm because she is a female. She does not have the right to have different identity in the colonial world. So Lyndall starts to challenge the colonial and patriarchal norms and values.

The Karoo farm land is a virgin land. They want to make it fertile and productive, that's why they colonize the Karoo farm land. With different pretentipn, they get entry into that farm land, as teachers of the school to teach the farm children. B onaparte Blenkins came into the farm land as a school teacher and at last he becomes the owner of the Otto's farm land. But new settlers want to own the land and show their identity yith that land. The Karoo farm land ultimately falls under the control of colonizers.

So, the characters are unsatisfied with their own identity. The writer exposes oppression of the character. I ndall is inspirational character to other oppressed characters in the colonial Karoo landscape. Qtros tamily 1 s new settler at the African farm landscape. They are settled by the first phase of colonization and face the problems of oppression in the farm land. They have farm and dojng their agro-business in it.

1.1 Statement of the problem

In this novel, Lyndall represents all the female characters and also he shows the condition of colonized people in the farm land. Females are dominated and oppressed by the colonizers. Schreiner tries to give freedom for females and give them their identity. Patriarchal and imperial power is always high and those powers dominate the women's power. That's why Schreiner's work is the voice against the patriarchal and imperial power structure. 


\subsection{Objective of the Study}

The main objective of this research is to discover why there is the crisis of identity of the female protagonist in the novel. Their identity is of female is connected with the place. They feel that the place or farm landscape gives her real identity. As the colonizers took the land or farm of the African people, they became dislocated and mainly the females had to face the crisis of identity. This research also shows how females raise their voice against the patriarchy, colonialism, and search for identity.

\subsection{Limitation of the Study}

This research paper is limited to the extensiva analysis of Oline Schreiner's novel, The Story of an African Farm as a primary text and the theory of postcolonial feminism has been used as a tool to interpret it.

\section{Review of Literature}

Many critics haye interpreted the novel from different perspectives. They have talked about struggle of wopnen. Freeman (2009) gives the idea about dissolution of landscape in the text. Here in the text place deternines the identity of the protagonist, Lyndall. The African farm landscape, the Karoo is connected with the Lyndall's identity. Her physical and spiritual connection with the Karoo land gives the identity of the protagonist Lyndall. Hannah describes the Schreiner's connection with the landscape, "discovering her attachment to the mysterious and barren South African plain" (18).

Likewise, the novel is also related with the natural landscape of African farm land. She shows the isolated and powerless nature of childhood in colonial Africa. Before colonial time, the Karoo is isolated and unproductive land, but during the colonial time, colonizer shifts the African new settlement to another place, and the Karoo landscape becomes fertile. 
In Karoo, there is a small family that runs the sheep farm. Otto is the owner of the farm, so there we find inequality between males and females.

Another critic Waterman (1997) presents his opinion on the power, gender and age, which determines the people's identity and their living place. He says that the issues of female identity and their displacement at the colonial world as:

Schreiner's frequent ambivalence stems perhaps from her own contradictory position within society, as a white Englishwoman whospent much or her life living and working in imperial South Africa ocapying both the position of colonizer, as the English subject and colonized, as a working elass woman (44).

It means he argues that female have the problem of identity and their living place. Their identity is related to the land.

So also, Esty (2007) says that The Story of an African Farm is that the novel which includes land and identity. Through Schreiners s text reader can understand nineteenth century situation of the African farm and italso reflect the lifestyle of the character in the text. To make female characer more intelligentin front of the colonizer, the writer has written the fiction. Lyndal is sukh a type grold protagonist who is challenging the colonizer to make her own identity in the colonial rule. The colonizer rules the farm people and gives them their identity. But 4 yndall does not want to accept the identity easily given by others.

Then, Holloway (1989) posits his idea about the novel's thematic and structural organization. He posits the manner in its thematic concerns and social constraints that have influenced the style and shape of the novel. He says:

No colonial or socio-ideological group is granted permanent, unmediated hegemony rather, interpersonal and intergroup relation are in constant state of flux. A first phase of colonial expansionism has violently wrested the land 
from its original inhabitants, the Bushmen leaving only remnants of their civilization. (81)

Here, they have their own origins and other social, cultural and economic backgrounds. They are not easily settled down at one place. This is the new settlement of the first phase of colonial expansion. The Story of an African Farm is set in the Karoo farm landscape. It is the place where many natural things are available and it has suitable climate for the agro- business. To justify the setting of the novel, it is divided into two parts

Similarly, in the novel, Bonaparte, is the representative character of the colonizers; who has the multiple identities in the farm. He introduces himself as a strangdr and gets easy entry in to the Otto's farm house and later he begonges the owner of the farm. Thus, the mission of Bonaparte is now somehow complete, and he changes hirs identity and the place following his mission. His mission is to control over the farm landscape and make the people slave. He displaces the Otto's family from them own farm land and becomes the master of that farm land. By the displacement of the farm Otto s children lose their identity.

Another critic Chapman (1998) also lalks about the problem of identity. He talks about the identity politios. South Afrjcan's identity is related to their race, culture and language. The cultury of the place becomes multiple because of interchanging with another place, whereas pervious culture loses its originality. They lose their identity. For African farm people at the time of apartheid to protect their culture, race and language is ambiguous, and their protection of culture, race and language is meaningless. They cannot separate their culture, race and language from the new settlers.

As in the Karoo farm land, there are English speaking people, their language is not meaningful in as they were Hottentots and Boer, who speak their own native language. English is worthless in that farm landscape. Chapman (1998) further argues that, under apartheid whites have racial and political superiority than black as: 
Under apartheid whites were given a political racial identity which coterminous with superiority utilized to its advantage either its western European inheritances or its long African rootedness with in this political racial identity. Afrikaner dam saw itself as culturally distinct from English speaking South African who were regarded as derivative of the English and since they had rapidly become town's people having little connection to the South African soil. (88-89)

In the African landscape, colonizer determines the colonized pgople's political, racial, and cultural identity. The native people have lost their identity and originalty in their own landscape. Colonizer utilizes power upon the Africe people to show their superiority. They use English language to show themselves superior to African people But later African had to copy English language to show them superior in front of the colonizer.

3. Methodology or Theoretical Framework

The researcher has used post-colonial heory to analyze the text. It presents the crisis of female identity that result from the Yack of their land. Dislocation is the cause of their identity crisis and colonizers tooktheir Karoo farm land, and colonizers make them having no identity at all.

In Key Concepts in Post-Colonial studies, Ashcroft (1998) defines dislocation as a:

Ayterm for both the occasion of displacement that occurs as a result of imperial occupation and the experience associated with this event. The phenomenon may be result of transportation from one country to another by slavery or imprisonment by invasion and settlement a consequence of unwilling movement from an unknown location. (73) 
Here, Ashcroft expresses his opinion of the term dislocation. People are dislocating from their own landscape willingly or unwillingly. But people are displaced from one place to another unknown place. It brings the identity crisis of new settlers in the new landscape. All the same, the colonized people have the feeling of displacement that comes through the behavior of the imperial ruler. They are being treated not like a human being; they think they are the things for their use.

In his Imperial Leather: Race, Gender, and Sexuality in the Colonial Contest, McClintock (1995) posits rights of females had been limited at the colontal time in the African farm land. Women were controlled by the white European males and their identity is also under the control of colonizers. Women's rights were limited in the colonial society. Women did not have their individual identity; their identity is connected with the men and place. The identity of female is made by the males.

So also, the writer says, "Colonial women before the intrusion of imperial rule, were invariably disadvantaged withm thetr societies, in ways that gave the colonial reordering of their sexual and economic tabor very differen outcomes from those of colonial men" (6). It means their life is ffected by the golonizers rule; the colonial rulers' behavior is cruel towards the colonized women. Among them even among the women, there was no sympathy among themselves.
The African colonized males also suffer from the colonial empire just like the females. They work for colonizers but it does not give them money.

Ashcroft (2001) gives his clear idea about the link between identity and place. They are interconnected with each other, without place people's identity is meaningless. People's identity and place have connection with each other. People's identity is determined by the place. If the place and identity are not connected with each other, they do not have their own identity. People's alienation is also caused by the displacement. 
In the Text, Theory, Space, the theorist Kate (1996) tells about the experience of women in the colonial world. She also further explains how they feel to live in the life of colonized in the world of colonizers. Olive herself is a traveler and she also has experienced the trauma of colony.

In $19^{\text {th }} \mathrm{C}$. British imperialism was in its full height on colonization, particularly in South Africa. There was strong urge for British women to bring their domestic culture in their colonies to preserve and reproduce their own culture at the colonies. At that time, middle class women were always oppressed by the upper class women and white males. $19^{\text {th }} \mathrm{C}$. imperial mission is not only establishing their colonial empire bu also to increase their territory among the whole world. Imperialism is the formation of an empire. Their strategies to make imperial world is to spread their culture, language and gain the economic things like ivory, diamond and other natural resources.

In The Post-colonial Studies Reader, Ashcrott (2001) (et.al) tell that hybridity occurs in different ways:

Hybridity occurs in post-colonial societies both as a result of conscious moments of cultural suppression, as when the colonial power invades to consolidate political and economic control or when settler invaders dispossess indigenous people and force them to assimilate to new social patterns. It may
also ocour in later periods when patterns of immigration from the metropolitan societies and from other imperial areas of influence (e.g. indentured laborers from India and china) continue to produce complex cultural palimpsests with the post- colonized world. (183)

It means, a new culture penetrates and tries to assimilate with indigenous culture and condition for hybridity emerges. In hybrid culture, powerful culture suppresses and invades local culture. The local identity loses its ground and gets mixed with new cultural experience. 
It brings conflict, domination; inequalities and power exercise in the people's mind. So, it brings various problems.

In Colonial and Post Colonial Literature Migrant Metaphors, Boehmer (1995) writes about the condition of women writing at the post colonial time. At the colonial time, colonized woman are victims of their identity and place. They are not allowed to go to public place and speak openly. Colonizers dominate them as their racial and feminine quality. Colonized woman are suppress their inner feeling and voice:

Native or subaltern women were, as it is called, doubly or triply marginalized. That is to say, they were disadvantaged on the groun not only of gender but also of race, social class and in same case religion, caste, sexuality and regional status. Far from being efadicated, the grim irony of the independence period was that the pressure of national liberation reinforced many of these forms of exclusion. Gender divisions in particular were often brought into greater prominence. $(216)$

It means native people andromen ard doubly and triply marginalized and their voice and identity are not acknowledged. Therr feeling was not respected in their own place and their same sex and women.

revisiting the afro-mentioned entire theoretical concepts, the researcher has interpreted the novel The Story of an African Farm by Oliver Schreiner. The protagonist Lyndall has the yoice of rebellion against the colonizers and she is in the search for identity. The colonizers had dislocated her from the farm land, which was the source of identity formation for her. 


\section{Textual Analysis from Postcolonial feminist Perspectives}

Olive Schreiner's The Story of an African Farm, focuses on the problem of female identity and their dislocation from their own place in colonized South Africa. There is the domination of the female characters or the colonized people that are dislocated from their own place. The colonized do not have their identity in their own place. Dislocation reflects their hybrid position in the land. The hybridity reinforces their dislocation as well as displacement from their own identity. These sorts of dislocation fragmentation and displacement which are in the novel, are the crucial features of post colpnial period:

Place in post-colonial societies is a complex interaction of langtage, history and environment. It is characterized firstly by a sense of displacement in those who have moved to the colonies or the more widespread sense of displacement from the imported language of a gap betweeh the experienced environment and description the language provides, and secondly by a sense of the immense investment of culture in the construction of place. (Ashcroft 391)

Place is not only the land, but-albo it reflects language, culture, history and environment. Thus longing for identity is related with different cultural, linguistic and historical factors. They are the sources of identity for people. The new settlers, African people are displaced by the cause of drought. In the Karoo farm land, they cannot produce any kind of food items and they are unable to run the sheep farm, so they are forced to change the place and settle down at new place. The native African people are facing the problem of migration by nature; nature also does not justice to the native people. There is a crisis of water. A colonizer makes dam for African people but the dam's water level decreases and finally dries.

In the novel, land is important to determine the identity of the protagonist. When people are dislocated from the place, their identity comes in crisis. So also, in the novel the 
main protagonist, Lyndall has the identity problem in her farm, Karoo. Lyndall loses her real place when Blenkins came there. Lyndall had to be displaced her from that land.

In Schreiner's novel, Otto's family is dislocated from their own farm land because of the the Englishman Bonaparte Blenkins, who control the Karoo Farm land and being the master of that farm land. His mission was to establishing the new settlement in that farm land. Olive Schreiner's The Story of an African Farm, reflects dislocation which is manifested through the female protagonist's ambivalence and conflict about cultural and social affiliation. Identity crisis is related to place, cultural rootlessness. In a sense, displacement and dislocation give way to alienation and hybridized situation which makes then realize loss of origin leading to the sense of homelessness.

In the novel, colonizers sell African farm people in to the Europe for labor. But farm people are not ready to go to Europe because there they lose their identity in the capitalist world. They are treated as a machine and lose the human quality. Colonizers want to shift farm people's identity according to their advantage. They also exploit them physically and economically. In the same axay, cyndall, a fenale protagonist also travelled many places for her job. "Lyndall was tired after her long journey and had come to her room early. Her eyes ran over the familiar)bbjects.' (109). She challenged Victorian concepts of women, who were staying at home bearing chlldren and caring them. Women were not allowed to go outside and get the knowledge of travel.

The women were not allowed to go outside. That's why women were doing their domestic work. Some women went for travel resisting the patriarchal rule and knew about the real world, and she wrote about it and expresses their feelings as the travelers. In woman's writing, they showed their identity in the outer world:

Their narrative focused on the difficulties of reproducing middle class homes in alien environment, where the amenities of civilized society were often 
sorely lacking. Discourse of domesticity characterized most female travel writing of the era and reflected the gender constraints of Victorian society notable the way in which middle class women lives and writing were circumscribed and defined by the women's sphere's home and hearth. (83)

It means, colonizers agent make entry in the neighboring country one by one take some mission on the African space which convince the African people. African people are feared to the Englishman, who had tall body structure and white skin. They are like the God for the African people. Em asked to Lyndall in the context of prophet:

He was one man only one' said her little companion slowly. Yet all the people in the world feared him. He was not born great; he was common as we are. Yet he was master of the world at last, onde he was only a yitye child, then he was a lieutenant then he was a general then he was an empleror. (11)

Here, Bonaparte imprisons Waldo at his house; Lyndall want to takeout her brother from hand of that cruel Englishman. She does not request him but challenges him. African has the problem of langrage which displaces in their farm land. The problem in the farm is that colonizers language is their mother longue, but Africans are not happy with the English language because this is the second language for them. That's why they are not fit in the place. Here, the concept of place and displacement creates the complex interaction of language, history and environment in the experience of colonized people.

For that reason, Language is one of the tools which brings in them helpless and having no identity in their own land. African aboriginal people use their native language. The new settlement of Karoo is the mixed farm land as is the diverse culture, race and languages. The new settlers are settled by the colonizers and they use English language, but native people cannot understand it. Their language is of gentleman's language. The English language is the great man's language and the superior for the African people. The colonizers 
may represent their superiority through the language; it is the means to dominate the farm people in the farm.

Schreiner has used the local words to give the novel a sense of originality and the locality of the African landscape; they are Kaffer, Kopje and Sleg. In the African farm landscape newcomers have not only language problem but also cultural and other social and political problems. Thus, in the post colonial context, Africans were forgetting their culture and mimic the colonizer's culture and the language

In the African farm land, African people look at then as strangers. Tant Sannie herself is an English speaking woman in the farm, but she also looks at theth a stranger. Their English is worthless as compared to the colonizers. African English speaker feels that they do not have any identity and place in the colonial landscape. Que to the effect of cultural hybridity, African new settlers are confused about their lahguage, which is the Standard English language or not. In this borderless wortd the African new settlers lose their original place; they move here and there. So, trans-ulture creates a borderless and hybrid culture where fixed independent and absolute identity/s impossible.

As Identity apd place determine the female's position in the Karoo farm land when they are unnarried they do not Yave stable identity and place. After marriage they have constant identity in the society. Colonial women's identity and place are shifted. Every woman identity is eonnected with their male counterparts; his status determines the female's identity in the society. When women get married with high profile man, woman's identity automatically becomes high. Tant Sannie is woman in the farm, whose identity is higher than other women, because she gets married with Englishman, Bonaparte Blenkins

In the novel, Schreiner presents Em as weakest person on God's earth, because she is the woman and does not have specific identity. Her identity is related with Waldo and Lyndall. Colonizers male make them weakest in the farm because they do not give them 
rights to do any hard work. They treat them as the playing things. Colonizers give them marginal space in the Karoo farm because of their feminine qualities. They measure African farm women quality, according to race, caste, religion and sexuality. These things make female weakest in the Karoo farm land. Colonial rule makes them weak and give them marginal position in the farm land.

In the farm land women are marginalized, they are marginalized according to social religious and sexuality. Here in the novel, even God also makes them marginal and weakest things on the earth. They were oppressed their feelings and voice. They are not alloyed to do work what male are doing. The colonized women are dominatec in terth of sexuality, Englishman's are acting like a husband and play with them and later colonizers leave and their life becomes worthless. In their love, Boer women are forgetting their original feminine identity, whether they are Dutch or Boer women. Their ident ty is replaced by the colonizers and they start to think as an Englishwomen not native African women.

In the above context, yndall speaks that "When I'm with you I never know that I am a woman and you are a man; I onl know thal we are both things that other men when I am with them, whether (love them or not, they are mere bodies to me; but you are a spirit; I like you" (129-130. It shows the loye between colonizer and the colonized women but this love is only for entertainment, not spiritual. When the women are with them they feel that they have Englishidentity. But it's not for long time. Englishmen consume their body and get pleasure; this is the reality of the colonial world.

Unfortunately, females are supposed to be the weakest. Colonizers think that women are the objects for the society and they are the play things for their counterparts' male and the white Englishmen. They find all the things what they want from them; women are like to the beautiful art object, "There is one art in which they are all necessary the delicate expressive 
body, the rich voice, and the power of mental transposition" (143). That art is very powerful art, where she presents her body as a unique art form.

In the novel, Schreiner displays the condition of colonized people, mostly the farm children who lose the love of her father recently. And the new farm owner, Bonaparte Blenkins, treats farm children like the animals; he always beats the child Waldo." The cruelty of the master colonizer of the farm could be seen here. He does not have any humanity upon the children. Bonaparte Blenkins beat him regularly and he is not allowed to speak in front of an Englishman. Waldo becomes totally silent in front $\mathrm{gf}$ the Blenkin

The writer challenges colonizers through her yriting but it's impossible in the colonial empire. Women's condition becomes worse day by day by the Englishman's domination. Their basic needs are also controlled by the coloniay empire and they have to take permission to work on the farm. They cannot do anything in their own will. They fulfill the Englishman's desire. What they want, Women should give them. Englishman is the master of that farm and dominates the entire farm workers, mostly the females are the victims of the colonizers. He exploits themphysically, mentally and geographically.

Lyndall and Walde are the yoyths but they have immature mind. They are badly affected by the potyerful sense of colonial empire. Lyndall's immature decision for not getting marriage is the violation of the social rule; she does not want to stay under anyone. "I am not in so-great a hurry to put my neck beneath any man's foot; and I do not so greatly admire the crying of babies, she said as she closed her eyes half wearing and leaned back in the chair" (110). Here, Lyndall's statement shows the immature decision to marry with Gregory Rose. In the farm, Bonaparte Blenkins wants to marry Lyndall with Gregory, because after her marriage there is a great chance for Blenkins to become more powerful in the farm land. 
In the novel, Olive Schreiner presents the dislocation from in their place and the identity crisis of the farm people in Africa. People's identity is connected with the place where they live and do their business. When they are dislocated from the place, their identity is in crisis. The same thing happens in the novel. When the Englishman Bonaparte Blenkins came in the Karoo Farm land, the owner of that farm is replaced by him. He becomes the master of that farm land, where he makes the children and women their slaves and they lose identity in their own farm land. The farm children Lyndall, Waldo and Em are struggling to re-establish their identity in that farm landscape.

The author presents the place as a symbol of identity formation. It is connected with the culture and identity of a person. If a person is difconnected with his/her place, she/he loses his/her cultural and identical ground. So, Place carries the people's identity and history of their culture, but colonizers exploit the colonized landscdpe. So the author presents the protagonist Lyndall is raising her voice for identity in the colonized state.

In conclusion the researcher finds out the identity crisis of Lyndall, the protagonist and her voice of rebellion against the colonizers. It means, the identity of female is related to the land, but she was made dislocated from the Karoo farm land by the colonizers. In the Schreiner's text, Lyndan is the main protagonist, who struggles for establishing her identity in the farm Yand.,But, she is unable to establish her identity in the Karoo farm land. She takes her last breath without getting identity in the farm landscape because she is a female. Her identity is relative to her male counterpart and his place, not her place. Here, identity crisis simply refers to the lack of specific cultural position in the farm land. Thus, Lyndall's identity is in crisis because of the colonizers male, colonizers displace her from the farm land. 
She is also a representative character of colonized South Africa as many females had the same fate there.

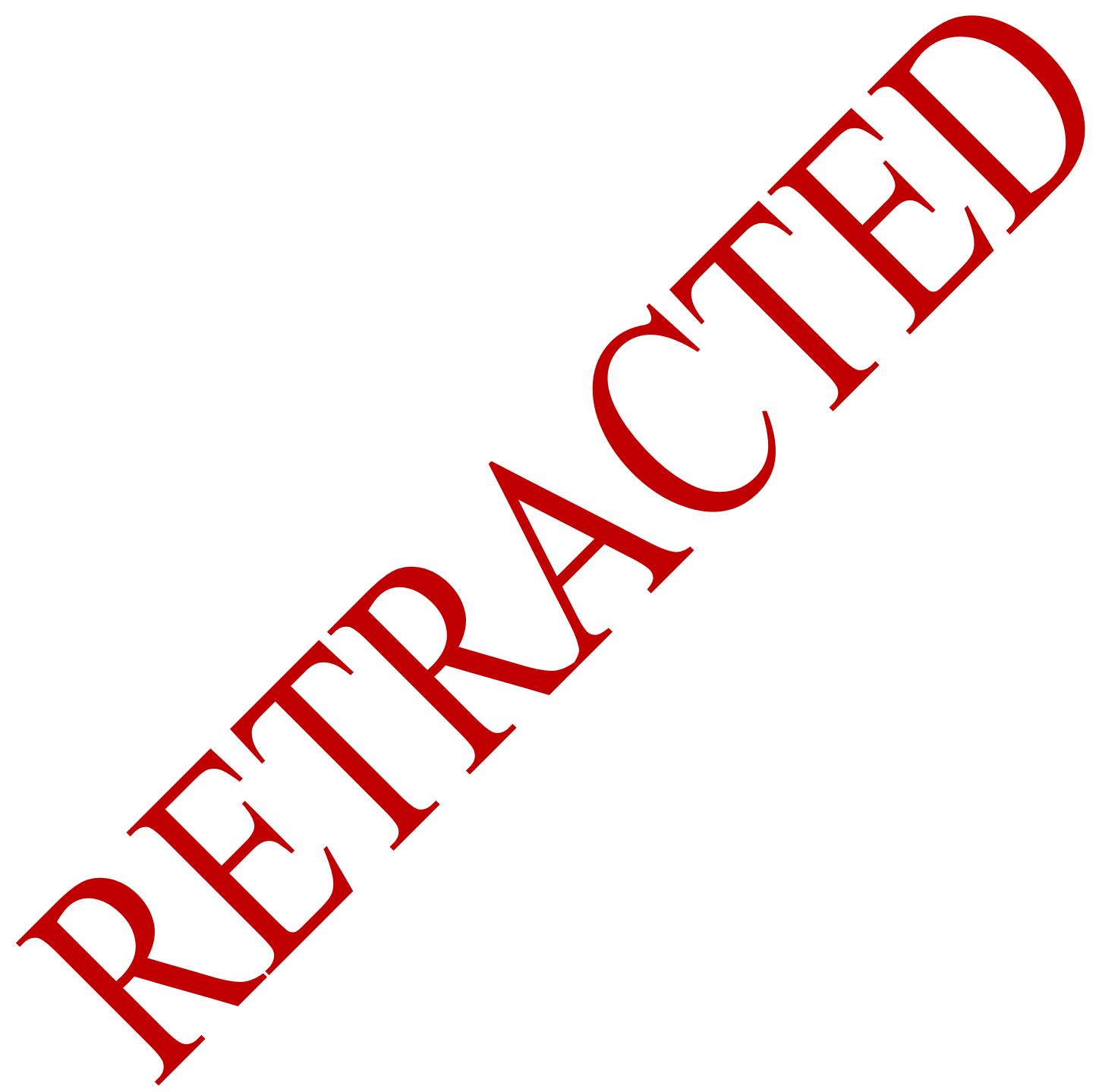




\section{References}

Ashcroft, B. (2001). Post-colonial Transformation. London: Routledge.

Ashcroft, B. (1998) et.al. The Key Concepts in Post-colonial Studies. New York: Routledge.

Boehmer, E. (1995). Colonial and Postcolonial Literature: Migrant Metaphors. Oxford: Oxford UP.

Chapman, M. (1998). "The Problem of Identity: South Africa, Storytelling, and Literary History." New Literary History. 29.1: 85-99.

Kate, D. S. (1996). Text, Theory, Space: Land, Literature and History in South Africa and Australia. London: Routledge.

Esty, J. (2007) "The Colonial Bildungsroman: The Story of an African Farn and the Ghost of Goethe." Victorian Studies. 49.3, pp. 40t-30.

Freeman, H. (2009) "Dissolution and Landscape: In Olive Schreiner's The Story Of An African Farm." English Studies in Arica. 52.2 pp.18-34.

Holloway, M. (1989). “Thematic and structural organization in Olive Schreiner's The Story of an African Farm. English in Africe. 16.2, pp. 77-89.

McClintock, A. (1995). Mmperial Leather: Race, Gender, and Sexuality in the Colonial Contest. New York: Routledge.

Schreiner, Q. (2008) The Story of an African Farm. London: Project Gutenberg.

Waterman, D. (1997) Jlive Schreiner's The Story Of An African Farm: Power, Gender And Age." English Studies in Africa. 40.1, pp. 43-61. 